\title{
An exploratory study on energy sustainability indicators for local energy planning
}

\author{
A. R. Neves \& V. Leal \\ Faculty of Engineering of the University of Porto-MIT-Portugal \\ Program, Portugal
}

\begin{abstract}
Energy challenges of today encompass a paradigm shift, moving from centralized systems focused on energy production to a decentralized management approach. Local authorities have an important role to play in promoting sustainable energy systems. Initiatives emerging in the European Union and in other parts of the world, such as the Covenant of Mayors or the Clinton Climate Initiative, stress the fact that cities are important actors for implementing sustainable energy policies and their actions must be encouraged and supported. However, current processes of energy planning and assessment at the local level are still lacking a common and systematic methodology for the evaluation of energy sustainability. The development of energy and climate change policies, as well as the implementation of sustainable energy action plans, stresses the need for monitoring and reporting the progress towards sustainable energy goals.

This paper presents a review on how energy is included in the main sets of sustainable development indicators and discusses its commonalities and differences. It also addresses the issues of applicability and measurability at the local level, since most of the energy indicators were designed to be used at the national level. It then attempts to identify existing gaps in the evaluation of local energy sustainability, and ends up with a proposal of a core set of indicators that can be used to assess in a comprehensive way the performance of local energy systems.

The local level set of indicators proposed seeks to provide insights to local decision-makers by measuring and tracking progress towards the several dimensions of sustainability in what regards the local energy system, and its management structure.
\end{abstract}

Keywords: energy sustainability indicators, local level, energy planning. 


\section{Introduction}

The need for assessment of local energy systems sustainability performance has become clear nowadays. Processes of energy planning at the local level are emerging, in response to energy and climate change policies. Initiatives, such as the Covenant of Mayors and the Clinton Climate Initiative also stress the fact that cities are important actors for implementing sustainable energy policies and that their actions must be encouraged and supported. More recently, local governments formally requested the adoption of a United Nations Climate Change Conference - Conference of Parties decision recognising and empowering the role of cities and local authorities in the implementation of National Climate Change Strategies and Action Plans [1]. However, current processes of energy planning and assessment at the local level are still lacking a common and systematic methodology for the evaluation of energy sustainability. There is an apparent need for structured methods for monitoring and reporting the status and the progress towards sustainable energy goals.

Although some local authorities have already initiated their processes of energy planning, it is possible to notice that there is a wide variety of approaches. The difference in the approaches undertaken might lead to the fact that not all the important issues are being addressed. In fact, a short review of the Portuguese case, where several energy agencies, both at municipal and at regional level have been emerging in the last decade, shows that there is a lack of an integrated approach to energy planning. From a total of 19 agencies identified (table 1), only one has announced a medium-term energy action plan and only two have set performance targets. There are only eight energy agencies that have started to diagnose the current situation, some of them using the energy matrix approach. The scope of most of the agencies is mostly focused on the implementation of some isolated measures or projects, such as promoting energy efficiency in public buildings, facilities and lighting, solar thermal and environmental awareness, among others.

Table 1: $\quad$ Portuguese energy agencies' activities, based on [2].

\begin{tabular}{|c|c|c|c|c|}
\hline $\begin{array}{c}\text { Energy } \\
\text { agencies }\end{array}$ & $\begin{array}{c}\text { Isolated } \\
\text { measures/projects }\end{array}$ & $\begin{array}{c}\text { Energy matrix } \\
\text { (diagnosis) }\end{array}$ & $\begin{array}{c}\text { Performance targets } \\
\left(\mathrm{CO}_{2}, \text { energy use) }\right.\end{array}$ & $\begin{array}{c}\text { Mid-term } \\
\text { action plan }\end{array}$ \\
\hline 19 & 17 & 8 & 2 & 1 \\
\hline
\end{tabular}

The adoption of energy sustainability indicators is fundamental to support energy planning processes as well as to assess energy sustainability at the local level. The aim of this paper is to propose a core set of indicators that are suitable to assess in a comprehensive way the performance of local energy systems towards sustainable development.

\section{Methodology}

Figure 1 presents the methodology adopted for the development of a core set of indicators for local energy sustainability. 


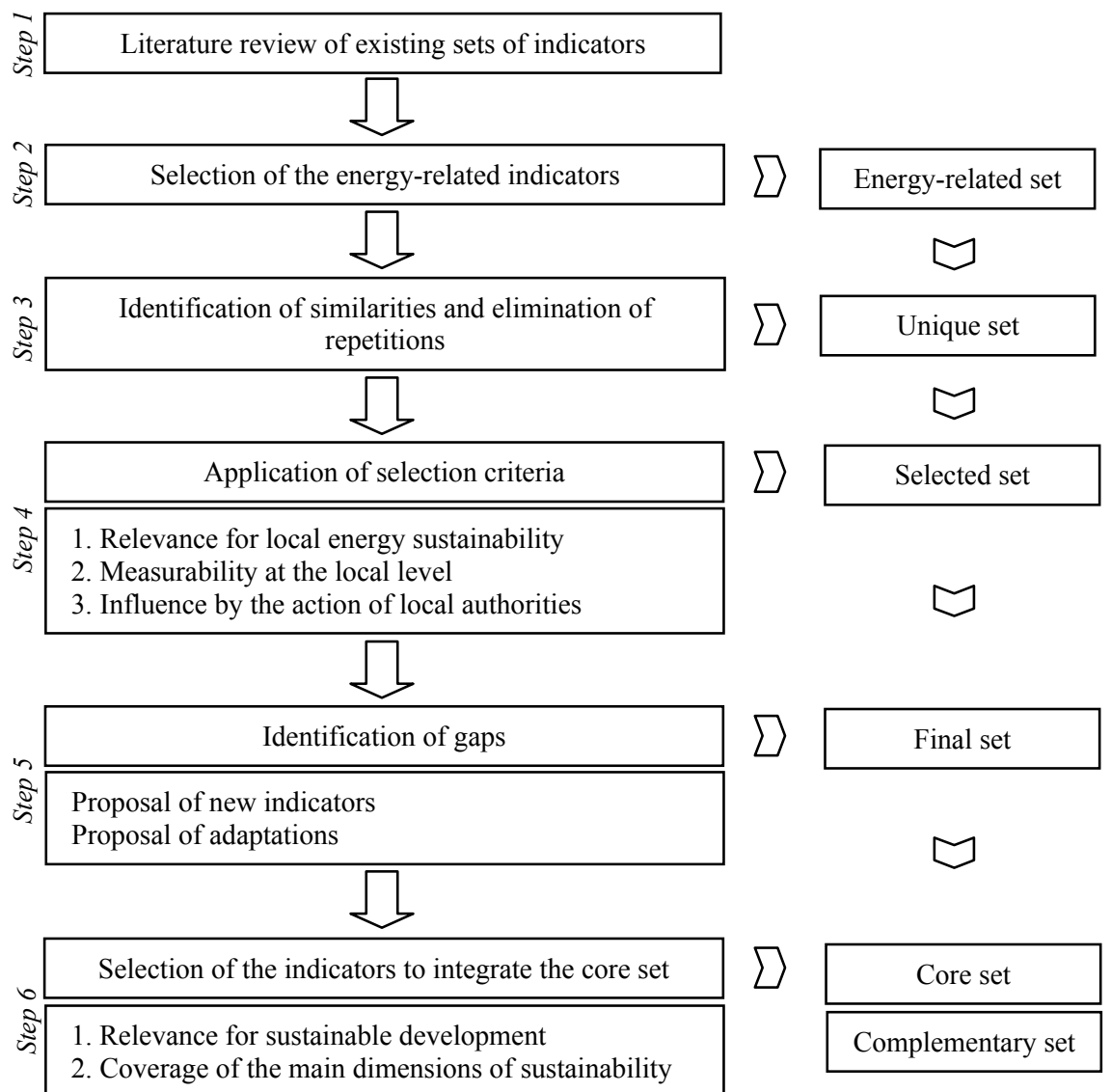

Figure 1: $\quad$ Methodology used for the identification of a core set of indicators for local energy sustainability.

It was initially performed a literature review of international sets of energy and sustainable development indicators, namely the Energy Indicators for Sustainable Development [3]; the United Nations Commission of Sustainable Development (CSD) Indicators of Sustainable Development [4]; Sustainable Development Indicators proposed by Eurostat Task-Force [5]; European Environment Agency core set of indicators [6]; European Common Indicators [7], and; Study on Indicators for Sustainable Development at the local level [8]. Publications on Sustainable Development sets of indicators in Portugal and Switzerland were also included in the literature review $[9,10]$.

Afterwards, it was conducted an identification of energy-related indicators contained in these publications. The indicators identified were then subjected to an analysis of similarities among them. Only unique indicators passed to the next stage, which involved the application of three selection criteria: 1) the relevance of the indicator for local energy sustainability; 2) its measurability at the local 
level, and; 3) if the factors that determine the indicator can be influenced by the action of the local authorities. The indicators that fulfilled simultaneously these three criteria were selected.

The next step was to make a critical evaluation of the set and to identify possible remaining gaps. There was the need to incorporate new indicators, as well as to adapt existing ones.

The process ended up with a final set of indicators for local energy sustainability. Due to the need of keeping the indicator set concise and manageable, the final set was divided into a core set of indicators and a larger set of complementary indicators. The indicators that make part of the core set were chosen by their relevance for sustainable development and coverage of the main dimensions of sustainability.

\section{Measuring sustainability: a literature review}

The use of indicators has been considered a fundamental tool to measure sustainable development. Agenda 21, the action plan for sustainable development, which resulted from the United Nations Conference on Environment and Development in 1992, calls countries to develop indicators of sustainable development. These indicators need to be developed to provide solid bases for decision-making at all levels and to contribute to a self-regulating sustainability of integrated environment and development systems [11]. The Aalborg Charter, approved in 1994 by the European Conference on Sustainable Cities and Towns, emphasizes the capacity of local authorities to solve some of the global environmental problems, as they are close to where environmental problems are perceived and closest to the citizens. It commits the signatory local authorities to the use of different types of indicators, including those of urban environmental quality, urban flows, urban patterns, and indicators of urban systems sustainability. The indicators are considered to be a supporting tool for policy-making towards sustainability, useful to describe and monitor current status and progress [12].

Several organizations in the last few years have been developing many works on sustainability indicators. The United Nations Commission of Sustainable Development (CSD) adopted a work programme on indicators of sustainable development in 1995. The indicators have been tested, applied and used in several countries. The revised third edition of the CSD indicators has been developed in response to decisions by the CSD and the World Summit on Sustainable Development in 2002, which encouraged further work on indicators at the country level. It contains a core set of 50 indicators which are part of a larger set of 96 indicators of sustainable development. The core set helps to keep the indicator set manageable, whereas the larger set allows the inclusion of additional indicators that enable countries to do a more comprehensive and differentiated assessment of sustainable development. The CSD recommends that indicators for sustainable development have to be [4]:

- $\quad$ Primarily national in scope;

- $\quad$ Relevant to assessing sustainable development progress; 
- $\quad$ Limited in number, but remaining open-ended and adaptable to future needs;

- Broad in coverage of Agenda 21 and all aspects of sustainable development;

- Understandable, clear and unambiguous;

- Conceptually sound;

- Representative of an international consensus to the extent possible;

- Within the capabilities of national governments to develop;

- Dependent on cost effective data of known quality.

The European Common Indicators (ECI) initiative has started in 1999 with the task to develop common indicators for local sustainability. Indicators have been developed according to a bottom-up approach, involving an extensive consultation with local authorities. This resulted in the agreement of a list of 10 common indicators. These indicators were selected by taking into consideration six Sustainability Principles: Equality and social inclusion; Local governance/empowerment/democracy; Local/global relationship; Local economy; Environmental protection, and; Cultural heritage/quality of the built environment. An indicator had to address at least three of the Sustainability Principles [7]. The Eurostat Task Force for Sustainable Development Indicators has elaborated a list of 155 indicators organised into 10 themes (Economic development; Poverty and social exclusion; ageing society; Public health; Climate change and energy; Production and consumption patterns; Management of natural resources; Transport; Good governance; Global partnership). These indicators have the aim of monitor, assess and review the European Union Sustainable Development Strategy [5].

The Joint Research Centre developed a study on Indicators for Sustainable Development at the local level. It aimed to review the state of the art on sustainable development indicators; to perform a comparative analysis of existing set of indicators; to propose a core set of indicators of sustainable development at local level; and, to perform a critical analysis of existing sets of indicators. According to this study, one criterion to distinguish "local" sustainability indicators from regional, national and global could be the extent to which the activities/impacts measured are within the gift of local decisionmakers or not. The study ends up with the proposal of 31 local sustainability indicators. The assessment of these indicators followed the "indicator assessment cobweb" approach, by using 10 attributes: analytical soundness; benchmarks/critical values; sensitivity; scale dependence; ease of data acquisition; comprehensibility; interpretability; interdependence; diagnostic power, and; policy relevance, scored on a seven point scale [8].

Yuan et al. focuses also on local sustainability indicators and on the role of public participation as a means of identifying indicators for a local community. The selection process of the indicators follows a bottom-up consultation process involving different local actors. As so, different aspirations and needs of different community groups are considered and discussed during the process [13].

Other initiatives at country level are for example the systems of sustainable development indicators for Portugal [9] and for Switzerland [10], where a set of indicators of sustainable development are identified for the country context. 
The Environment European Agency has developed a core set of 37 indicators which aim to support the European Union policy priorities. It covers six environmental themes: air pollution and ozone depletion; climate change; waste; water; biodiversity, and; terrestrial environment, and four sectors: agriculture; energy; transport, and; fisheries. The core set is primarily designed for EU and national level policy makers [6].

With respect to energy indicators, the International Atomic Energy Agency (IAEA) in cooperation with other international organizations such as the United Nations Department of Economic and Social Affairs (UNDESA), the International Energy Agency (IEA), the Statistical Office of the European Communities (Eurostat) and the European Environment Agency (EEA) has developed the project on Energy Indicators for Sustainable Development (EISD). This project was conceived to fill the need for a consistent set of indicators applicable worldwide; to assist countries in the energy and statistical capacity building necessary to promote energy sustainability, and; to supplement the work on general indicators being undertaken by the CSD. It is expected that countries will use the EISD to assess their energy systems and to evaluate progress towards sustainability. The EISD core set of 30 indicators is categorized according to three dimensions: social, economic and environment, which are then categorized into themes and sub-themes. It does not follow the DSR (driving force, state and response) type categorization of indicators used by UNDESA [14] due to its unwieldy and definitional difficulties. It is important to note that the indicators need to be read in the context of each country's economy and energy resources. The indicators taken together and in context, allowing for inherent differences between countries, can give a good picture of a country's energy system [3]. The procedures and processes to develop and use EISD depend on country-specific conditions, national energy priorities and sustainability and development criteria and objectives. The implementation process depends on the existing statistical capacity, expertise and the availability of energy data. The proposed set of indicators represents a quantitative tool necessary but not sufficient for monitoring progress and for defining long-term strategies. There are issues that are difficult to quantify which need to be taken into account. It is the case of the institutional dimension of sustainable development. Institutional questions are sometimes considered to be responses and not readily quantified as indicators [15]. However, indicators to reflect the institutional dimension are being developed and may be incorporated into the EISD at a later stage [3].

\section{Results}

\subsection{Energy approaches in sustainable development indicators sets}

The main sets of sustainable development indicators analysed present always some indicators related to energy and its causal relationships with the environment and economy. Table 2 shows how energy is included in the main sets of sustainable development indicators studied. 
Table 2: Number of energy-related indicators encountered in the sets of indicators analysed, by themes.

\begin{tabular}{|l|c|c|c|c|c|c|c|}
\hline \multirow{2}{*}{$\begin{array}{l}\text { Indicators } \\
\text { Themes }\end{array}$} & \multicolumn{7}{|c|}{ Sets of indicators } \\
\cline { 2 - 8 } & {$[4]$} & {$[5]$} & {$[6]$} & {$[7]$} & {$[8]$} & {$[9]$} & {$[10]$} \\
\hline $\begin{array}{l}\text { Climate change } \\
\text { and air quality }\end{array}$ & 3 & 7 & 4 & 2 & 1 & 1 & 3 \\
\hline $\begin{array}{l}\text { Energy } \\
\text { intensities }\end{array}$ & 2 & 2 & 1 & - & - & 1 & - \\
\hline Fuel mix & 2 & 5 & 4 & - & - & 2 & 1 \\
\hline $\begin{array}{l}\text { Energy demand } \\
\text { (sectors) }\end{array}$ & 1 & 2 & 2 & - & - & 1 & 3 \\
\hline $\begin{array}{l}\text { Transport } \\
\text { modes }\end{array}$ & 2 & 9 & - & 2 & - & 1 & - \\
\hline Other themes & 1 & 5 & - & - & - & 1 & - \\
\hline Total & 11 & 30 & 11 & 4 & 1 & 7 & 7 \\
\hline
\end{tabular}

[4] CSD Indicators of Sustainable Development

[5] Sustainable Development Indicators proposed by Eurostat Task-Force

[6] EEA core set

[7] European Common Indicators

[8] Study on Indicators for Sustainable Development at the local level

[9] System of Sustainable Development Indicators for Portugal

[10] Sustainable Development in Switzerland - Factors for an indicator system

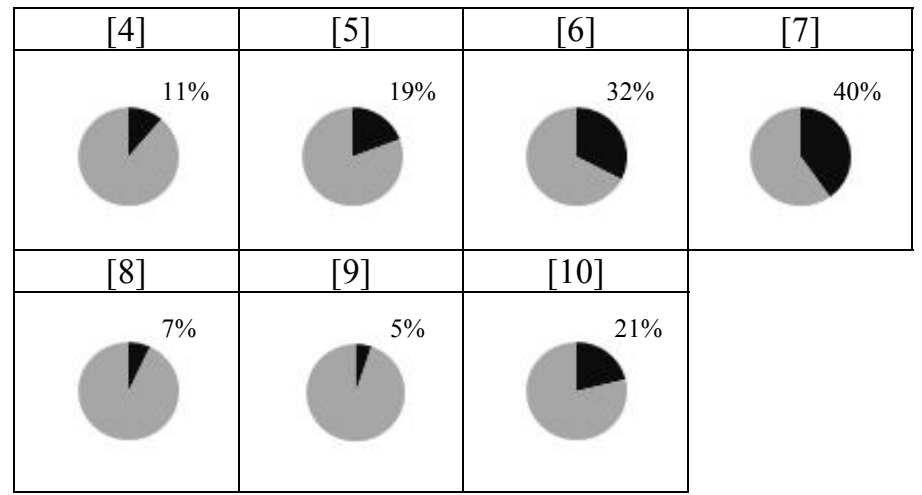

Figure 2: Shares of energy-related indicators (coloured in black) encountered in the sets of indicators analysed.

Figure 2 illustrates the representativeness of energy-related indicators in the sets of sustainable development indicators analysed. It is possible to note that are sets that give more relevance to energy-related indicators than others, this is the case of the EEA core set [6] and the European Common Indicators [7].

It was possible to find some similarities in these sets of indicators in what regards the energy-related indicators used. For instance the presence of indicators of climate change such as carbon dioxide $\left(\mathrm{CO}_{2}\right)$ or greenhouse gases $(\mathrm{GHG})$ emissions was very frequent. Other indicators regularly mentioned were the ones that give information on the energy use and its fuel mix, as well as on the modes of transport used. 
Table 3: $\quad$ Indicators that fulfilled the three selection criteria.

\begin{tabular}{|c|c|c|}
\hline Theme & Indicator & Unit of measurement \\
\hline \multirow{14}{*}{ Economic } & $\begin{array}{l}\text { Share of household income spent on fuel and } \\
\text { electricity }\end{array}$ & $\%$ \\
\hline & Energy use per capita & toe (p.e. and f.e.) per capita \\
\hline & Industrial energy intensities & toe (f.e.) per Euro \\
\hline & Agricultural energy intensities & toe (f.e.) per Euro \\
\hline & Service/commercial energy intensities & toe (f.e.) per Euro \\
\hline & Household energy intensities & toe (f.e.) per capita \\
\hline & Transport energy intensities & $\begin{array}{l}\text { toe (f.e.) per pkm and per } \\
\text { tkm }\end{array}$ \\
\hline & Fuel shares in energy and electricity & $\%$ \\
\hline & Renewable energy share in energy and electricity & $\%$ \\
\hline & Business demography & n.a. \\
\hline & $\begin{array}{l}\text { Annual energy consumption, total and by main } \\
\text { user category }\end{array}$ & toe (p.e. and f.e.) \\
\hline & Modal split of passenger transport & $\%$ of $\mathrm{pkm}$ \\
\hline & Final energy consumption by sector & toe (f.e.) \\
\hline & Energy consumption by transport mode & toe (f.e.) \\
\hline \multirow{5}{*}{ Environmental } & $\begin{array}{l}\text { GHG emissions from energy production and use, } \\
\text { per capita and per unit of Gross Domestic Product }\end{array}$ & $\begin{array}{l}\text { tonnes of } \mathrm{CO}_{2} \text { eq. per capita } \\
\text { and per unit of GDP }\end{array}$ \\
\hline & GHG emissions by sector & $\begin{array}{c}\text { tonnes of } \mathrm{CO}_{2} \text { eq. per capita } \\
\text { and per unit of GDP }\end{array}$ \\
\hline & $\mathrm{CO}_{2}$ emissions & annual $\mathrm{CO}_{2}$ in $\mathrm{Gg}$ \\
\hline & $\begin{array}{l}\text { Ambient concentrations of air pollutants in urban } \\
\text { areas }\end{array}$ & $\mu \mathrm{g} / \mathrm{m}^{3}$ or $\mathrm{mg} / \mathrm{m}^{3}$ \\
\hline & $\begin{array}{l}\text { Emissions of air pollutants from transport } \\
\text { activities }\end{array}$ & tonnes \\
\hline \multirow{3}{*}{ Social } & Attendance at community group meetings & n.a. \\
\hline & Access to public transport & n.a. \\
\hline & $\begin{array}{l}\text { Responses to European Commission internet } \\
\text { public consultations }\end{array}$ & n.a. \\
\hline Governance & E-government on-line availability & n.a. \\
\hline
\end{tabular}

n.a. - not available. p.e. - primary energy. f.e. - final energy

\subsection{Development of a core set of local energy sustainability indicators}

After performing a review of the main sets of sustainable development and energy indicators, there were identified 110 indicators that were related to energy and its causal relationships with environment, economic and social issues. However, most of these indicators presented similarities among them, and so it was necessary to eliminate repetitions. After such repetitions were eliminated, 
(step 3 in figure 1), it was reached a number of 61unique indicators. Afterwards, these 61 indicators were subjected to another selection process to determine whether they should be considered for the local level or not (step 4). This was performed based in three criteria: 1) the relevance of the indicator for local energy sustainability; 2) its measurability at the local level, and; 3 ) if the factors that determine the indicator can be influenced by the action of the local authorities. From the 61 indicators analysed, there were 23 indicators that fulfilled simultaneously these three criteria (table 3 ).

Table 4: $\quad$ Adaptations of existing indicators.

\begin{tabular}{|c|c|c|}
\hline Existing indicators & Adapted indicator & Unit of measurement \\
\hline $\begin{array}{l}\text { Responses to European } \\
\text { Commission internet public } \\
\text { consultations }\end{array}$ & \multirow{2}{*}{$\begin{array}{l}\text { Responses to public consultations } \\
\text { of energy-related projects }\end{array}$} & \multirow{2}{*}{$\%$} \\
\hline $\begin{array}{l}\text { Attendance at community group } \\
\text { meetings }\end{array}$ & & \\
\hline E-government on-line availability & $\begin{array}{l}\text { E-government on-line energy- } \\
\text { related information availability }\end{array}$ & Qualitative description \\
\hline $\begin{array}{l}\text { GHG emissions from energy } \\
\text { production and use, per capita and } \\
\text { per unit of GDP }\end{array}$ & $\begin{array}{l}\text { GHG emissions from energy use, } \\
\text { per capita and per unit of GDP }\end{array}$ & $\begin{array}{l}\text { tonnes of } \mathrm{CO}_{2} \text { eq. per } \\
\text { capita and per unit of } \\
\text { GDP }\end{array}$ \\
\hline Business demography & $\begin{array}{l}\text { Ratio of energy-related jobs to } \\
\text { population }\end{array}$ & Jobs/10 000 inhabitants \\
\hline $\begin{array}{l}\text { Annual energy consumption, total } \\
\text { and by main user category }\end{array}$ & $\begin{array}{l}\text { Annual energy consumption per } \\
\text { capita by main use category }\end{array}$ & toe (f.e.) \\
\hline
\end{tabular}

f.e. - final energy

Table 5: $\quad$ Proposal of new indicators.

\begin{tabular}{|l|c|}
\hline \multicolumn{1}{|c|}{ New Indicator } & Unit of measurement \\
\hline $\begin{array}{l}\text { Locally available finance schemes for renewables and energy } \\
\text { efficiency }\end{array}$ & Qualitative description or \% \\
\hline $\begin{array}{l}\text { Energy production from microgeneration in relation to } \\
\text { consumption }\end{array}$ & pkm/year \\
\hline $\begin{array}{l}\text { Travel distance by mode of transport } \\
\text { Awareness raising campaigns on energy issues }\end{array}$ & Qualitative description \\
\hline $\begin{array}{l}\text { Advice on building projects and assistance to the citizens on } \\
\text { energy issues by the local authority }\end{array}$ & Qualitative description or \% \\
\hline $\begin{array}{l}\text { Active public participation in energy-related policy-making } \\
\text { Ratio of local renewable production to local consumption of } \\
\text { energy and electricity }\end{array}$ & $\%$ \\
\hline
\end{tabular}


Having these 23 indicators, it was then performed an analysis to investigate whether there were some gaps that needed to be filled (step 5). The identification of these gaps resulted in the adaptation of six existing indicators (including merging two of them) and in seven new indicators being added, by the initiative of the authors. Table 4 presents the adaptations made to existing indicators while table 5 shows the proposal of new indicators.

The final set of local energy sustainability is thus composed by 29 indicators (from 23-1+7). Taking into account the need to keep a small set in order to be concise and manageable for local decision-makers, it was decided to define a core set of indicators (step 6). The choice of the indicators that make part of the core set took into consideration their relevance for local sustainability and that the set would assure the coverage of the main pillars of sustainability. As so, the core set is composed by eight indicators while the complementary set is composed by 21 indicators. Table 6 presents the indicators that constitute the core set.

Table 6: $\quad$ Core set of local energy sustainability indicators.

\begin{tabular}{|c|c|c|}
\hline \multicolumn{2}{|r|}{ Core set of Indicators } & Units \\
\hline \multirow{2}{*}{$\begin{array}{l}\text { Energy } \\
\text { demand }\end{array}$} & Primary energy use per capita & toe (p.e.) per capita \\
\hline & Annual energy consumption per capita by main use category & toe (f.e.) per capita \\
\hline $\begin{array}{l}\text { Endogenous } \\
\text { energy }\end{array}$ & $\begin{array}{l}\text { Ratio of local production to local consumption of energy } \\
\text { and electricity }\end{array}$ & $\%$ \\
\hline Local economy & Ratio of energy-related jobs to population & $\begin{array}{l}\text { Jobs/ } 10000 \\
\text { inhabitants }\end{array}$ \\
\hline \multirow{2}{*}{$\begin{array}{l}\text { Climate } \\
\text { change and air } \\
\text { quality }\end{array}$} & $\begin{array}{l}\text { GHG emissions from energy use, per capita and per unit of } \\
\text { GDP }\end{array}$ & $\begin{array}{l}\text { tonnes of } \mathrm{CO}_{2} \text { eq. } \\
\text { per capita and per } \\
\text { unit of GDP }\end{array}$ \\
\hline & Ambient concentrations of air pollutants in urban areas & $\mu \mathrm{g} / \mathrm{m}^{3}$ or $\mathrm{mg} / \mathrm{m}^{3}$ \\
\hline $\begin{array}{l}\text { Public } \\
\text { engagement }\end{array}$ & Active public participation in energy-related policy-making & $\begin{array}{c}\text { Qualitative } \\
\text { description or } \%\end{array}$ \\
\hline $\begin{array}{l}\text { Economy- } \\
\text { Governance }\end{array}$ & $\begin{array}{l}\text { Locally available finance schemes for energy efficiency and } \\
\text { renewable energy }\end{array}$ & $\begin{array}{c}\text { Qualitative } \\
\text { description or } \%\end{array}$ \\
\hline
\end{tabular}

\section{Conclusions}

This paper has reviewed the main initiatives on sustainable development indicators, with the aim of investigating how energy was included and of performing a selection of the indicators that could be appropriate to evaluate energy sustainability at the local level. All the sets of indicators studied included energy-related indicators, with strong similarities among them, mostly in indicators to evaluate the impact of energy use in climate change. By performing an elimination of repetitions it was possible to reduce to about half the indicators 
identified, reaching 61 different indicators. It was however also clearly identified that most of the indicators were designed to be used at the national level.

The methodology adopted has led to the proposal of a preliminary core set of eight indicators to evaluate local energy sustainability. This work still needs to be tested, what is expected to be done soon with pilot municipalities in order to identify possible weaknesses of the set and to collect feedback from the main users.

\section{References}

[1] ICLEI (2008). Municipal Commissioner Nadkumar Jantre, Thane, India, addresses delegates at United Nations Framework Convention for Climate Change Conference on behalf of Local Governments and Municipal Authorities (LGMA): Cities, Local Authorities and Climate Change, viewed 18 December 2008, <http://www.iclei.org/fileadmin/template/ conference_templates/poznan_2008/files/PDFs/high_level_segment_Jantre 12 Dec.pdfs.

[2] RENAE (Rede Nacional de Agências de Energia), 2008, Membros RENAE, viewed 2 October 2008, <http://www.renae.com.pt/ membros.asp $>$.

[3] IAEA (International Atomic Energy Agency), 2005, Energy Indicators for Sustainable Development: Guidelines and Methodologies, International Atomic Energy Agency, Vienna.

[4] UN (United Nations), 2007, Indicators of Sustainable Development: Guidelines and Methodologies, Third Edition, New York.

[5] Eurostat, 2005, Final report of the Sustainable Development Indicators Task-Force, First meeting of the Working Group on Sustainable Development Indicators, Meeting of 5-6 April 2005, Luxembourg.

[6] EEA (European Environmental Agency), 2005, EEA core set of indicators, Guide, EEA Technical report, No 1/2005, European Environment Agency, Copenhagen.

[7] AIRI (Ambiente Italia Research Institute), 2003, European Common Indicators - Towards a Local Sustainability Profile, Ambiente Italia Research Institute, Milan, Italy.

[8] JRC (Joint Research Centre), 2004, Study on Indicators of Sustainable Development at the Local Level, European Commission DirectorateGeneral Joint Research Centre, Italy.

[9] APA (Agência Portuguesa do Ambiente), 2007, Sistema de Indicadores de Desenvolvimento Sustentável, SIDS - Portugal, APA.

[10] Montmollin, A. de and Altwegg, D., 2000, Sustainable Development in Switzerland, Factors for an indicator system, A pilot study based on the methodology of the United Nations Commission on Sustainable Development (CSD), Swiss Federal Statistical Office, Swiss Agency for the Environment, Forests and Landscape, Neuchâtel. 
[11] United Nations Sustainable Development, 1992, Agenda 21, United Nations Conference on Environment and Development, Rio de Janeiro, Brazil, 3 to 14 June 1992.

[12] Charter of European Cities \& Towns Towards Sustainability, 1994, European Conference on Sustainable Cities \& Towns, Aalborg, Denmark.

[13] Yuan, W. et al., 2003, 'Development of sustainability indicators by communities in China: a case study of Chongming County, Shangai', Journal of Environmental Management, no. 68, pp. 253-261.

[14] UNDESA (United Nations Department of Economic and Social Affairs), 2001, Indicators for Sustainable Development: Guidelines and Methodologies, United Nations Department of Economic and Social Affairs, New York.

[15] Vera, I. and Langlois, L., 2007, 'Energy indicators for sustainable development', Energy, no. 32, pp. 875-882. 